\title{
Anna-Lena SENDER
}

Jagiellonian University in Kraków

a.l.sender@student.rug.nl

\section{INDISPENSABLE PARTNER \\ OR SIGNIFICANT OTHER?}

\section{GERMAN AND FRENCH MEDIA PORTRAYALS OF POLAND AFTER 25 YEARS OF WEIMAR TRIANGLE}

ABSTRACT With the intention of the German, French and Polish foreign ministers to bring their countries closer together after the fall of the Iron Curtain, the Weimar Triangle was founded in 1991. This setting has enabled an institutionalised regional cooperation on the governmental level as well as between the respective civil societies. However today, in a Europe of permanent crises and protracted uncertainty, a risky divergence between Germany, France and Poland seems to emerge. Since the Polish national elections in October 2015 has brought the right-wing, nationalist Law-and-Justice-party (PiS) into power, we are also witnessing a rising relevance of domestic political determinants for mutual contacts. Facing this new period of tension, where more closeness and trust would be required, discursive attitudes and strategies of 'othering' might gain ground and lead to increasing alienation. Based on the assumption that the portrayal of a country could be both the first step towards creating and obtaining a more inclusive or exclusive identity, this paper aims to find out the following: in how far are German and French media about to pre-cook patterns of asymmetry and alienation? Or follow they rather an inclusive and comprehensible approach towards Poland? These questions are exemplified by the biggest centre-left and centre-right German and French daily newspapers Süddeutsche Zeitung, Frankfurter Allgemeine Zeitung, Le Monde and Le Figaro, whereas the corpus of data is limited to the period of the year 2016. By making use of the critical discourse analysis, this paper provides information about to what extent Poland is considered to be a close and indispensable partner as 
well as to where we can identify mechanisms of putting the country aside as a significant other.

Key words: Weimar Triangle, media discourse, European identity

Słowa kluczowe: Trójkąt Weimarski, dyskurs mediów, tożsamość europejska

\section{INTRODUCTION}

With the intention of the German, French and Polish foreign ministers to bring their countries closer together, striving for an ever-closer integrating Europe, the Weimar Triangle was founded in 1991. This setting has enabled an institutionalised regional cooperation on the governmental level as well as between the respective civil societies. Despite the rather asymmetric trilateral partnership many factors have facilitated and ensured the relations during the last quarter-century. ${ }^{1}$ However today, most of the background factors are under threat. In a Europe of permanent crises and protracted uncertainty, a risky divergence between Germany, France and Poland could emerge. Since the national elections in October 2015 has brought the right-wing, nationalist Law-and-Justice-party (PiS) into power, we are also witnessing a rising relevance of domestic political determinants for mutual contacts. Facing this new period of tension, discursive attitudes and strategies of 'othering' might gain ground and lead to increasing alienation in a period where more closeness and trust are required.

Whereas the ongoing demarcation of 'us' and 'them' characterizes many debates in all European member states (such as polarized discussions on the EU asylum policy), inclusion and exclusion are important theoretical concepts to interpret new developments in our societies and to define the on-going global and local conflicts and struggles. ${ }^{2}$ Based on the assumption that the portrayal of a country's society could be both the first step towards creating a more inclusive or exclusive identity, the thesis aims to find out to what extent German and French media are about to pre-cook patterns of asymmetry and alienation - or if they rather follow an inclusive and comprehensible approach towards Poland.

Therefore, this investigation will take a closer look at how the German and French media reflect on their close European partner on the occasion of the $25^{\text {th }}$ anniversary of the Weimar Triangle. While also having in mind the governmental change since the elections in October 2015 the main question is: how is Poland portrayed in German and French media? The idea behind is to connect the politically initiated project of the Weimar Triangle to the today's social and cultural dimension of the relations by looking

See K.-O. Lang, "Preserving the Unity of a Fragmenting Europe", New Eastern Europe, no. 6 (2016), p. 228.

2 See R. Wodak, “Us' and 'Them': Inclusion and Exclusion - Discrimination via Discourse”, in G. Delanty, R. Wodak, P. Jones (eds.), Identity, Belonging and Migration, Liverpool 2011, p. 54. 
into the media discourses of the 'old' partners France and Germany about their 'new' one Poland.

The question of Poland images in French and German media is exemplified by the biggest centre-left and centre-right German and French daily newspapers Süddeutsche Zeitung, Frankfurter Allgemeine Zeitung, Le Monde and Le Figaro. Since not only the governmental change in Poland but also the $25^{\text {th }}$ anniversary of the trilateral partnership serve as a significant occasion for German and French media to reflect on their relationship with Poland (and its position within the broader framework of the EU), the corpus of data will be limited to the period of 2016.

The study of contemporary exclusion and inclusion is not straightforward and thus necessarily implies a critical qualitative in-depth analysis. Hereby, the critical discourse analysis is most useful for this kind of approach since it allows a reflection on broader mechanisms of inclusion and exclusion. In that sense, the investigation will be followed by a critical interpretation of the findings: how are Poland's cultural and political affiliations (i.e. in reference to the categories of East and West or toward its position within the EU) negotiated in the media? To what extent is Poland considered to be a close and indispensable partner and where can we identify mechanisms of putting the country aside as a significant other?

\section{THEORETICAL FRAMEWORK}

The theoretical framework of this study considers external perception to be important indicators of how (national) intentions have been translated into (European-wide) observable and observed actions. In the field of international relations, studies of images have been popular since the $1950 .{ }^{3}$ During the Cold War, external perceptions and images were considered within image theory of foreign policy. ${ }^{4}$ In the 1980s, Siamak Movahedi argued that images and perceptions of other nations would provide the basic framework within which the conduct of international relations and conflict resolution takes place. ${ }^{5}$

A recent review of the perceptions studies in international relations scholarship shows that the edited volume on the evolution of EU perceptions by Natalia Chaban and Martin Holland significantly contributes to the applicability of perception theory

\footnotetext{
See K.E. Boulding, The Image. Knowledge in Life and Society, Ann Arbor 1956; idem, "National Images and International Systems", Journal of Conflict Resolution, vol. 3, no. 2 (1959), pp. 120-131.

4 See R.K. Herrmann, Perceptions and Behavior in Soviet Foreign Policy, Pittsburgh 1985; B. Silverstein, "Enemy Images: The Psychology of U.S. Attitudes and Cognitions Regarding the Soviet Union", American Psychologist, vol. 44, no. 6 (1989), p. 903, at <http:/dx.doi.org/10.1037/0003-066X.44.6.903>; idem, C. Flamenbaum, "Biases in the Perception and Cognition of the Actions of Enemies", Journal of Social Issues, vol. 45, no. 2 (1989), pp. 51-72, at <http://dx.doi.org/10.1111/j.1540-4560.1989. tb01542.x>.

5 S. Movahedi, "The Social Psychology of Foreign Policy and the Politics of International Images", $\mathrm{Hu}$ man Affairs, no. 8 (1985), p. 22.
} 
to the following analysis. The scholars seek to systemise the academic field by creating a theoretical model which can be applied in the following way: firstly, perceptions are issue-, location-, time- and cohort-specific, and that they are influenced by factors that are germane to Poland, external counterparts and the global community. ${ }^{6}$ Secondly, time-related changes to any imagery can happen on three levels: histoire de longue durée, ${ }^{7}$ histoire conjuncture ${ }^{8}$ and micro histoire, ${ }^{9}$ whereas the latter will be the main temporal dimension for this proposed research question. It is at the level of micro histoire where a crisis (or multiple crises) trigger re-categorizations of an international actor in a very short time span.

In the scenario of Poland, the main issue guiding the perception of Poland is the victory of right-wing, nationalist PiS party and its follow-up actions. The Polish governmental change falls in the context of a rising nationalism in neighbouring, post-communist countries, notably the Hungarian government with its illiberal stance. The cultural-geographical position of Poland also plays a role in the sense that the newly installed PiS government joined and strengthened the Visegrad group's firm alliance against the proposed EU refugee quota. In line with this, the perception is chronologically framed by the so-called refugee crisis of the EU, which started in 2015. Moreover, the rising popularity of the FN in France and the AfD in Germany, prior to the national elections in 2017, plays into the perception of the political situation in Poland.

While studying the various uses of the East within processes of European identity formation, Iver Neumann states: Since nation-building and region-building projects are both instances of identity politics, they will necessarily have a unifying as well as a divisive aspect. The all-important question, rather, is how differentiation is produced. ${ }^{10}$ Taking this quotation as the guiding question, the role of the media is crucial in the context of discursive practices within the triangle, since media coverage continuously reflects on the interplay between new political statements, plans and laws on the one hand and the public sphere on the other. Ella Shohat and Robert Stam state that the perception of another country is highly dependent upon the news media. Even more, media representations of a foreign actor are viewed as a significant contribution into informing and educating the citizenship in order to participate in the domestic debate on foreign policy. ${ }^{11}$

6 See N. Chaban, M. Holland, "Introduction: The Evolution of EU Perceptions: From Single Studies to Systematic Research", in iidem (eds.), Communicating Europe in Times of Crisis. External Perceptions of the European Union, London 2014, p. 12, at <http://dx.doi.org/10.1057/9781137331175_1>.

7 Re-categorization of an international actor due to evolutions over centuries, e.g. Europe's discovery and exploration of the world during several centuries.

8 Re-categorization occurs due to permutations over 25-50 years like the European integration process with its many projects, from Common Agricultural Policy and Schengen zone to enlargement and common currency.

9 See N. Chaban, M. Holland, “Introduction...”, p. 14.

10 I.B. Neumann, Uses of the Other. 'The East' in European Identity Formation, Minneapolis 1999, p. 33.

11 E. Shohat, R. Stam, Unthinking Eurocentrism. Multiculturalism and the Media, London 2014, p. 46. 
Exemplified by the example of contemporary Polish-German relations, Agnieszka Szymańska also argues about the significant influence of media coverage (foreign reporting) on public opinion and the political discourse, wherefore the representation and image of a given country are crucial. ${ }^{12}$ Moreover, the quality (frequency, scope and presentation) of foreign reporting is decisive for the perception of events, the emergence and change of the national image as well as the attitude of the recipients towards the country and its society. While the media are just one instance for international communication and a source of information and knowledge among others, Szymańska’s study shows that Western European societies create their associations on Poland via online and printed media. The perception of Poland in Western Europe are mainly based on political statements of foreign reporting and only marginally on other means of sources or actual experiences. ${ }^{13}$

The study of contemporary exclusion and inclusion within the media discourse is not straightforward and thus necessarily implies a critical qualitative in-depth analysis. The critical discourse analysis (CDA) is most useful for this kind of approach since it includes a reflection on broader discursive mechanisms and helps to make visible the understanding of how language functions in constituting and transmitting knowledge as well as in exercising power. ${ }^{14}$ While the discourse analysis is interpretative and explanatory, its additional critical element implies a methodological connection of the selected texts with social circumstances, ideologies and power relations. ${ }^{15}$

\section{METHODOLOGY}

The analysis is conducted according to the following broad set of questions: What are the discursive attitudes? On the one hand, where do the discursive mechanisms include Poland as an important partner? And, on the other hand, where can we find demarcation of 'us' and 'them'? Which strategies of 'othering' can be identified? These questions are exemplified by the biggest centre-left and centre-right German and French daily newspapers Süddeutsche Zeitung, Frankfurter Allgemeine Zeitung, Le Monde and Le Figaro within the year 2016 (1 January 2016-31 December 2016).

The choice of sources is motivated by three factors: the level of representation for the country, the comparability across both countries as well as its responsiveness to a broader scope of research. On the one hand, it can be presumed that these dailies

12 A. Szymańska, "Information, Meinung, Macht, Manipulation. Die Rolle der Medien in den deutsch-polnischen Beziehungen”, in D. Bingen et al. (eds.), Erwachsene Nachbarschaft. Die deutsch-polnischen Beziehungen 1991 bis 2011, Wiesbaden 2011, p. 421.

13 See ibid., p. 422.

14 R. Wodak, M. Meyer, "History, Agenda, Theory and Methodology. Theoretical and Methodological Aspects of Foucauldian Critical Discourse”, in iidem (eds.), Methods of Critical Discourse Studies, London 2009 , p. 9.

15 N. Fairclough, "The Discourse of New Labour: Critical Discourse Analysis", in M. Wetherell, S. Taylor, S. Yates (eds.), Discourse as Data. A Guide for Analysis, London 2001, p. 235. 
(recognised as quality papers) have the biggest national impact in terms of opinion-shaping for a serious readership and decision makers of the country. This applies to the online and the printed version alike. ${ }^{16}$ On the other hand, these sources deliver information on day-to-day occurrences so that one can estimate the importance and closeness of Poland for each country: How frequent is the coverage? What is covered and how much space is given to the coverage? What is the dominant tone of the everyday-perspective on Poland? What are the most common topoi?

Table 1. German and French sources for the research

\begin{tabular}{|c|c|c|}
\hline & Centre-Left/Liberal & Centre-Right/Conservative \\
\hline Germany & Süddeutsche Zeitung (SZ) & Frankfurter Allgemeine Zeitung (FAZ) \\
\hline France & Le Monde (LM) & Le Figaro (LF) \\
\hline
\end{tabular}

Source: own elaboration.

Furthermore, the additional component of the media's political position enables not only a more representative sample for each country. It also widens the scope of research by looking into different political ideologies behind the media coverage of Poland's political situation: Does the Poland portrayals differ significantly between a more liberal and a more conservative coverage/between the German and French liberal newspaper and the right ones? What aspects of Poland's (changing) political situation are stressed? Are certain discursive patterns country- or ideology-specific?

\section{DATA ANALYSIS AND DISCUSSION}

After a first sampling of the material, it becomes evident that the most repetitive patterns are the political activities of the PiS government and its ideological motivation, the tensions within the European Union, in the NATO (with Russia) as well as the societal division within Poland. By means of a more in-depth analysis, the discourse can be clustered within three main narratives or 'fragments': the international rise of populism, disintegrative and illiberal tendencies; the narrative of Poland's specific history, religious, societal and cultural structure; and the narrative of European (active) citizenship and culture.

At the first glance, the articles can be categorised according to their main topic in the sense that they either mainly cover something on Poland or that they just mention Poland within the article. Quantitatively, the most articles on Poland (as well as articles which mention Poland) are published in January, covering the 'attacks' of the new

16 See "zeit.de Traffic Statistics", Alexa, at <http://www.alexa.com/siteinfo/zeit.de>; "faz.de Traffic Statistics", Alexa, at <http://www.alexa.com/siteinfo/faz.de>; "monde.fr Traffic Statistics", Alexa, at <http://www.alexa.com/siteinfo/monde.fr> and "figaro.fr Traffic Statistics", Alexa, at <http://www. alexa.com/siteinfo/figaro.fr>, 13 January 2016. 
PiS government against the rule of law and the freedom of speech in Poland. This applies to all the four newspapers. However, we can see that there are significantly more article published in the German media (FAZ: 34, SZ: 45) than in the French (LM: 24, $L F: 14)$. The numbers also tell that the news in Poland clearly attract more attention from left-liberal than right-conservative newspapers. While quantitative finding can give a first indication for how to understand the given material, it is necessary to have a closer look at the quality of the articles.

The reporting on Poland can be located in three main sections 'Politics' (compromising 'Politik' and 'Politique'), 'International' (compromising 'International', 'Monde', 'Politik' and 'Europa') as well as 'Culture' (compromising 'Culture, 'Idées', 'Kultur' and 'Feuilleton'). They are just a few relevant articles published in the section 'Economy' which can be explained with the topics that are tackled the most: the constitutional debate within Poland and with the EU Commission, the media reform, the formation of the Visegrad group against the EU refugee quota plan, the NATO mission in Poland and the Baltic States (in conflict with Russia) as well as the abortion law. Additionally, there are slightly more minor topics for the discourse about Poland, like the specific diplomatic tensions between the German and the new Polish government, the Brexit referendum, the visit of the pope in Krakow, Wrocław as European capital of culture, as well as the elections in the USA and in Austria. All of these topics can be listed as relevant discursive events of the year 2016 which are, in turn, entangled by the aforementioned four main narratives.

In terms of the Weimar Triangle itself, there are in total only 14 articles with a reference to it (FAZ: 3, SZ: 5, LM: 2, LF:4). Among them, nine articles just briefly mention as an institutionalised forum (and its $25^{\text {th }}$ anniversary) between the three countries. Three articles $(S Z)$ are written on the very topic but rather informative. Only two articles ( $L M$ and $L F)$ actually discuss the triangle, its future potential and Poland's role within this triangle: $L F$ published one article in September after the EU summit in Bratislava about a new European élan including the Eastern countries (pays de l'Est) based on common security interests for a EU defence project. The coverage sounds quite surprised and still sceptic about the apparently new tone of the Visegrad group leaders towards a new EU project. However, the article also speaks about a tangible réchauffement in this context, announcing a Weimar Triangle summit in November in France which had been suspended for five years. Now, an enlargement of the Triangle by Hungary, Slovakia and Check Republic is also under discussion. This indicates the attempt to overcome the fracture, between Poland on the one hand and France and Germany on the other, which was recently deepened by the close cooperation of the new Polish within the Visegrad group. ${ }^{17}$

However, the second article, published by Le Monde in November, speaks of Poland's choice for isolation from its most important partners within the EU, namely France

17 See J.-J. Mével, “UE: les pays de l'Est se rallient au projet de défense européenne”, Le Figaro Premium, 13 September 2016, at <http://premium.lefigaro.fr/international/2016/09/13/01003-20160913ARTFIG00275-ue-les-pays-de-l-est-se-rallient-au-projet-de-defense-europeenne.php>, 13 January 2016. 
and Germany, not the Visegrad countries. The current relations are described to be freezing cold and officially deteriorated because the trilateral summit was cancelled by France. Apart from the fact that Warsaw has rejected the helicopter deal, the article explains the cancellation by listing all the fields of great disagreement: the refugee question, the future of the EU, a European defence, the rule of law and European values in general. There would have been no way to find any common position. Instead, as it is interpreted, the only point of the summit could have been for the PiS government to legitimise its anti-European position. At the same time, it is said that Poland (not the Franco-German couple) has everything to lose in this game and lists all the disadvantages Poland is facing now because of being en délicatesse with France and Germany; Orbán's Hungary would be the only ally left. The article closes by saying that PiS decided for isolation within the camp occidental (despite its great potential after the fall of communism and that would be a pity. So, the main message of the article is that Poland would have the potential to be an engine country for Europe, however this has been reversed by its political leaders. ${ }^{18}$

Therefore, French media portray Poland as a quite dispensable and distant partner by deploring the missed opportunity (It is a pity) without recommending any top-down activities for an improvement of the relations. It is also the exception rather than the rule that one can identify references to an exchange on the civil society level between France and Poland (with the example of French support for Polish women against the new abortion law). German media, on the other hand, cover in a rather informative way on the diplomatic relations with Poland. Hereby, it is striking that the German newspapers remain completely silent about the failure of the trilateral cooperation. Instead the focus is exclusively set on the bilateral relations with Poland which are also under tension on the diplomatic level but in good order and condition between the citizens as it appears to be from the coverage. However, with reference to the EU level as well as to the ties between German and Polish citizens, we can find plenty of political statements which suggest Poland to be an indispensable partner.

In order to deconstruct the mechanisms which include Poland or exclude it as an 'other' (country-, society- or culture-wise), the discursive narratives also function as codes. Additionally, the material is organized by means of different sub-codes like religion, history, military, public opinion, demography, citizenship and culture. The coding helps to identify the dimensions in which it seems significant to put Poland aside, or not. Due to the first theoretical assumptions on which the investigation is based on, special attention is paid to the term pairs (PiS) government vs. Polish society, Eastern vs. Central vs. Western Europe and old vs. young democracy.

The consequences of the governmental turn (described as swing to the right) are framed within the range of crisis (e.g. crisis of the state or national crisis - FAZ, ice age $S Z$, threat $-L F$, conservative revolution and authoritarian excesses $-L M)$. The Polish crisis is threating the fundamental pillars and general functioning of the EU as well as the German-Polish rapprochement in particular which is considered to be the key for

18 See "Pologne: le choix de l'isolement", Le Monde, 2 November 2016, at <http://www.lemonde.fr/ idees/article/2016/11/02/pologne-le-choix-de-l-isolement_5024119_3232.html>, 13 January 2016. 
integrating the ex-Europe of the East. While Poland is often recognised to be one of the most important members of the EU, it turns - together with its recently closest partner Hungary into a new bloc of the East, anti-liberal and Eurosceptic. The new Polish leaders are also called ultraconservatives, anti-Brussels and sovereignists. ${ }^{19}$ Here, we can clearly see an othering of Poland in connection with its Visegrad partners, but notably Hungary. In the $S Z$ they are called The unwilling and The enemies and often made responsible for the fragmentation of the EU. ${ }^{20}$ Moreover, the discourse provides explanations about the emergence which are distinct from other phenomena of right-wing movements in other parts of Europe - especially when it comes to the reluctance of the refugee quota. The most striking and explicit examples can be found in LF: The hostility towards refugees is a question of culture and religion, much more than of partisan politics or colouring. ${ }^{21}$

On the other hand, there are also attempts to put the Polish developments within the broader context of a transnational rise of (right-wing) populism. The $S Z$ delivers the strongest statements in this regard. $L M$ also tends to interpret it rather like a European or global trend, while Polish news are frequently linked to the threat within the own country, namely Marine Le Pen. In this sense, one can state that the rather left-wing, liberal dailies consider the crisis in Poland to be a transnational phenomenon, while $F A Z$ and $L F$ give more space to explanations which frame it as an other - national or Central Eastern European - issue. However, this observation is not valid for every article but should rather be understood as a significant tendency.

Furthermore, it can be noticed that the allocation of Poland to a specific region is not coherent at all, although it still bears certain logic of contextualisation. Either Poland is put in the category of the Western world (however rarely), Central Europe (mostly in reference to the Visegrad group), Eastern Europe (most commonly used) or it is simply framed as the East (in connection with history, culture as well as past and future of the EU). It appears to be common sense among all the four newspapers that the new government (and its newly enforced regional partnership) is not only bad for the cooperation on the EU level (désamour européene - LM), but also for the Polish citizens themselves. Hereby, it is not clear if the authoritarian change of Poland is just implemented through a smart strategy of the PiS government or if the anti-liberal tendencies are deeply rooted in the Polish society itself.

As for specific national characteristics, Poland is generally portrayed to be rather conservative, very catholic (with a long clerical tradition and a significant amount of fundamentalist church districts $)^{22}$ as well as to have an exceptional need for secu-

19 See J.-J. Mével, "L’Union européenne menacée par ses fractures”, Le Figaro, 18 January 2016, at <http://premium.lefigaro.fr/international/2016/01/18/01003-20160118ARTFIG00342-1-union-europeenne-mena-cee-par-ses-fractures.php>, 13 January 2016.

20 See B. Peters, B. Galaktionow, "Vor dem EU-Gipfel Die Willigen und die Unwilligen", Süddeutsche Zeitung, 17 February 2016, at <http://www.sueddeutsche.de/politik/vor-dem-eu-gipfel-die-willigen-und-die-unwilligen-in-der-fluechtlingskrise-1.2865586>, 13 January 2016.

21 See J.-J. Mével, “L’Union européenne menacée...”

22 See F. Hassel, "Kein einfacher Kowalski”, Süddeutsche Zeitung, 31 May 2016, at <http://www.sueddeutsche.de/kultur/polens-rechte-kein-einfacher-kowalski-1.3013486>, 13 January 2016. 
rity, coupled with the feeling of being threatened (usually by Russia, but partly also by Germany or the EU). On the one hand, the $F A Z$ frames a specific Eastern European identity referring to Poland's geopolitical and geostrategic position as sandwiched in a rather comprehensible, empathic way. On the other hand, several articles stress the aspect of Polish paranoia by using terms like Polish large manoeuvres, anxieties and sensitivities. ${ }^{23}$ Whereas these estimates are often presented to be in direct confrontation with European values, it is also underlined that there is a deep divide within the country itself. Therefore, one cannot come to the conclusion that Poland would be significantly different from Germany and France as a whole. Instead, the reports are explicitly creating a foe image of the whole apparatus around the Polish government, while mostly embracing the Polish citizens as a group of people being on the best way to European citizenship.

There are of course differences in the way the Polish society is portrayed. However, the dominant tone is that the active (or recently mobilised) citizens can be easily identified as Europeans. To give an example, Wrocław, the cultural capital of Europe 2016, is widely referred to as an expression for liberalist, active and transnationally connected Polish citizens. ${ }^{24}$ At the same time, the society as a whole does not seem to be ready to share the European identity (which is not further explained within the articles) in an equal way with the French and German, for instance. In this context, the media speak of tensions within Polish identity (crispations identitaire - LM), an ideological cleavage, the other Poland etc. While the $S Z$ and $L F$ draw a rather optimistic image of Poland's future (framing its recent problems as a very serious but short-term phenomenon), we can find more dark prospects in the FAZ (Losing the way) and LM - policy of self-isolation).

Subsequently, this cannot simply be explained by the medias ideological or national background. Instead, the findings can be understood through a combination of the two factors, individually applied to each newspaper: the centre-left German newspaper shows a big effort to tie Polish and German citizens together over common values as well as a joint destiny and responsibility for the European project. $L M$, however, expresses a lot of criticism and pessimism because it uses this more sceptical narrative in combination with the emerging crises for France with the potential success of the

23 See M. Martens, "Osteuropäische Identität: Die Eingeklemmten", Frankfurter Allgemeine Zeitung, 25 May 2016, at <http://www.faz.net/aktuell/feuilleton/debatten/iwan-krastew-und-oliver-jens-schmitt-zu-osteuropa-14250809.html>; "Polnisches Großmanöver: Zehntausende Soldaten gegen die Angst", Frankfurter Allgemeine Zeitung, 7 June 2016, at <http://www.faz.net/aktuell/politik/ ausland/europa/polen-probt-grossmanoever-anakonda-2016-mit-grossbritannien-usa-14273702. html >; H. Bubrowski, "Rechtsstaatsverfahren der EU: Polnische Befindlichkeiten”, Frankfurter Allgemeine Zeitung, 19 January 2016, at <http://www.faz.net/aktuell/politik/euro-paeische-union/ rechtsstaatsverfahren-der-eu-polnische-befindlichkeiten-14023141.html>, 13 January 2016.

24 See J. Bisky, "Zwerge, Helden, Lech Wałęsa”, Süddeutsche Zeitung, 11 March 2016, at <http://www. sueddeutsche.de/kultur/polensnationalkonservativewende-zwerge-helden-lech-wasa-1.2902630>; J. Iwaniuk, "Wroclaw 2016 veut porter les valeurs de 'l'autre Pologne', Le Monde, 27 January 2016, at <http://abonnes.lemonde.fr/culture/article/2016/01/27/wroclaw-2016-veut-porterles-valeurs-de-l-autre-pologne_4854329_3246.html?xtmc=pologne\&xtcr=44>, 13 January 2016. 
Front National. While $L F$ appears to be more neutral with his estimation of Poland's status quo (embedding it in wider, historical and regional context of the ex-communist states), the $F A Z$. pays more attention to the power obsession of the PiS government and provides a lot of arguments for the fact they are on the best way to impose their specific conception of the Polish national identity in the long run.

On the political, institutional level the perception in French and German media differ to a remarkable extent. France seems to appreciate Poland's potential as an important European partner, especially in terms of a project-oriented cooperation (like a common European defence and security strategy). Still, the media discourse shows that the two countries currently have a very distant and alienated relation on the political level. The political events in Poland are frequently covered, also in a differentiated way, but they are primarily used to critically observe the status quo of the EU, including threats to the rule of law, human rights etc. and (at least by $L M$ ) to raise awareness about the worrying success of Marine Le Pen.

Germany, however - apart from single German politicians on the EU level, like Günther Oettinger, remains quite silent about the recent diplomatic tensions. Still, the countries seem to be entangled to such a great extent and in many different fields that the coverage appears to mostly have a very inclusive tone toward Poland. Nevertheless, the tone tends to be more distinct and sceptical in respect of Poland's Catholic Church, its demands for armament, the politics of history and culture of remembrance. At the same time, it is especially these fields that are strongly connected to the PiS government which is in turn consistently and unanimously connected with negative attributes.

\section{CONCLUSION}

One can come to the conclusion that Poland is considered to be a close and indispensable partner on the level of the limited (but growing) part of the society which is opposing itself against the PiS-government. At the same time, the country is put aside as a significant other when it comes to the governments initiatives and all the aforementioned aspect of Poland's cultural, historical, political and societal structures which are used to explain them. In this sense, the protesting Poles are framed as us, Europeans, whereas the PiS-government and its supporters are consistently and unanimously connected with negative attributes (them). Subsequently, the main discursive strategy appears to differentiate the like-minded Europeans living in the East but being confronted with another structural context then we, the (Western European), French and German people do. One aforementioned article with the title The other Poland gets to the heart of this observation: it portrays a Poland that is far away but gets partially closer to its Western partners Germany and France through the awakening civil society and opening culture in Poland.

In addition to that one can state a great importance of the ideological (cross-national) factor when it comes to how Poland's cultural and political affiliations are negotiated in the media. Given the political position of the newspaper, the interaction 
of Poland with France and Germany within the EU and the specific regional integration will either be based on regional, essentialising ( $F A Z$ and $L F)$ or transnational, normative ( $S Z$ and $L M)$ assumptions. While the latter (centre-left, liberal dailies) tend to discredit populism and nationalism in general, the former (centre-right, conservative dailies) tend to discredit rather the Central European populism and nationalism in particular.

Furthermore, it follows from the above that the trilateral partnership is rather structurally founded, not necessarily on the basis of a vivid, close and regular exchange which would be covered in the media. An active trilateralism does not seem to be prepared to meet the political and diplomatic challenges of today. Although a couple of articles try to invoke the importance of the Weimar Triangle, this only takes a minor role in the recent discourse and is framed as a temporarily lost case; while still having a great potential for the future European unification process. Subsequently, it is of great importance what kind of prospects are given for the Polish democracy which could not be tackled with the scope of this paper.

In general, further research should be addressed to the time dimension of the coverage in order to compare the first reactions and interpretations of the media to the events in Poland with rather long-term observations by journalists. Same applies for the analytical dimensions of the bilateral relations (differences and similarities between France and Germany) as well as the political spectrum (differences and similarities between liberal and conservative). Both dimensions would need a more extensive quantitative analysis in order to make the respective units comparable and, therefore, the findings even more profound. Nonetheless the paper finally could point out observable trends and some crucial details which serve as first sources of knowledge about current perceptions of Poland in France and Germany. Furthermore, the analysis builds a promising basis for further investigations on on-going complex conflicts of the trilateral cooperation - which is not exclusively important but essential for the future unification process in Europe.

\section{BIBLIOGRAPHY}

\section{Sources}

Bisky J., "Zwerge, Helden, Lech Wałęsa", Süddeutsche Zeitung, 11 March 2016, at <http:// www.sueddeutsche.de/kultur/polensnationalkonservativewende-zwerge-helden-lech-wasa-1.2902630>.

Bubrowski H., "Rechtsstaatsverfahren der EU: Polnische Befindlichkeiten", Frankfurter Allgemeine Zeitung, 19 January 2016, at <http://www.faz.net/aktuell/politik/euro-paeische-union/rechtsstaatsverfahren-der-eu-polnische-befindlichkeiten-14023141.html $>$.

"faz.de Traffic Statistics", Alexa, at <http://www.alexa.com/siteinfo/faz.de>.

"figaro.fr Traffic Statistics", Alexa, at <http://www.alexa.com/siteinfo/figaro.fr >.

Hassel F., "Kein einfacher Kowalski", Süddeutsche Zeitung, 31 May 2016, at <http://www.sueddeutsche.de/kultur/polens-rechte-kein-einfacher-kowalski-1.3013486>. 
Iwaniuk J., "Wroclaw 2016 veut porter les valeurs de 'l'autre Pologne”, Le Monde, 27 January 2016, at <http://abonnes.lemonde.fr/culture/article/2016/01/27/wroclaw-2016-veut-porterles-valeurs-de-1-autre-pologne_4854329_3246.html?xtmc=pologne $\& x t c r=44>$.

Martens M., "Osteuropäische Identität: Die Eingeklemmten”, Frankfurter Allgemeine Zeitung, 25 May 2016, at <http://www.faz.net/aktuell/feuilleton/debatten/iwan-krastew-und-oliver-jens-schmitt-zu-osteuropa-14250809.html>.

MévelJ.-J., “L'Union européennemenacéeparsesfractures”,Le Figaro, 18January2016, at <http:// premium.lefigaro.fr/international/2016/01/18/01003-20160118ARTFIG00342-1-union-europeenne-mena-cee-par-ses-fractures.php $>$.

Mével J.-J., “UE: les pays de l'Est se rallient au projet de défense européenne”, Le Figaro Premium, 13 September 2016, at <http://premium.lefigaro.fr/international/2016/09/13/01003-20160913ARTFIG00275-ue-les-pays-de-l-est-se-rallient-au-projet-de-defense-euro peenne.php>.

“monde.fr Traffic Statistics”, Alexa, at <http://www.alexa.com/siteinfo/monde.fr>.

Peters B., Galaktionow B., "Vor dem EU-Gipfel Die Willigen und die Unwilligen”, Süddeutsche Zeitung, 17 February 2016, at <http://www.sueddeutsche.de/politik/ vor-dem-eu-gipfel-die-willigen-und-die-unwilligen-in-der-fluechtlingskrise-1.2865586>.

"Polnisches Großmanöver: Zehntausende Soldaten gegen die Angst", Frankfurter Allgemeine Zeitung, 7 June 2016, at <http://www.faz.net/aktuell/politik/ausland/europa/polen-probt-grossmanoever-anakonda-2016-mit-grossbritannien-usa-14273702.html >.

"Pologne: le choix de l'isolement", Le Monde, 2 November 2016, at <http://www.lemonde.fr/ idees/article/2016/11/02/pologne-le-choix-de-l-isolement_5024119_3232.html>.

“zeit.de Traffic Statistics”, Alexa, at <http://www.alexa.com/siteinfo/zeit.de>.

\section{Literature}

Boulding K.E., The Image. Knowledge in Life and Society, Ann Arbor 1956.

Boulding K.E., "National Images and International Systems", Journal of Conflict Resolution, vol. 3, no. 2 (1959).

Chaban N., Holland M., "Introduction: The Evolution of EU Perceptions: From Single Studies to Systematic Research", in iidem (eds.), Communicating Europe in Times of Crisis. External Perceptions of the European Union, London 2014, at <http://dx.doi. org/10.1057/9781137331175_1>.

Fairclough N., “The Discourse of New Labour: Critical Discourse Analysis”, in M. Wetherell, S. Taylor, S. Yates (eds.), Discourse as Data. A Guide for Analysis, London 2001.

Herrmann R.K., Perceptions and Behavior in Soviet Foreign Policy, Pittsburgh 1985.

Jones P., Krzyzanowski M., "Identity, Belonging and Migration: Beyond Constructing 'Others"', in G. Delanty, R. Wodak, P. Jones (eds.), Identity, Belonging and Migration, Liverpool 2011.

Keller R., Diskursforschung. Eine Einführung für SozialwissenschaftlerInnen, Wiesbaden 2007.

Kundera M., “The Tragedy of Central Europe”, transl. by E. White, New York Review of Books, vol. 31, no. 7 (1984).

Lang K.-O., "Preserving the Unity of a Fragmenting Europe”, New Eastern Europe, no. 6 (2016). Movahedi S., "The Social Psychology of Foreign Policy and the Politics of International Images", Human Affairs, no. 8 (1985). 
Neumann I.B., Uses of the Other. 'The East' in European Identity Formation, Minneapolis 1999. Shohat E., Stam R., Unthinking Eurocentrism. Multiculturalism and the Media, London 2014.

Silverstein B., "Enemy Images: The Psychology of U.S. Attitudes and Cognitions Regarding the Soviet Union”, American Psychologist, vol. 44, no. 6 (1989), at <http://dx.doi. org/10.1037/0003-066X.44.6.903>.

Silverstein B., Flamenbaum C., "Biases in the Perception and Cognition of the Actions of Enemies”, Journal of Social Issues, vol. 45, no. 2 (1989), at <http://dx.doi.org/10.1111/ j.1540-4560.1989.tb01542.x>.

Szymańska A., "Information, Meinung, Macht, Manipulation. Die Rolle der Medien in den deutsch-polnischen Beziehungen", in D. Bingen et al. (eds.), Erwachsene Nachbarschaft. Die deutsch-polnischen Beziehungen 1991 bis 2011, Wiesbaden 2011.

Wodak R., “Us' and 'Them': Inclusion and Exclusion - Discrimination via Discourse”, in G. Delanty, R. Wodak, P. Jones (eds.), Identity, Belonging and Migration, Liverpool 2011.

Wodak R., Meyer M., "History, Agenda, Theory and Methodology. Theoretical and Methodological Aspects of Foucauldian Critical Discourse", in iidem (eds.), Methods of Critical Discourse Studies, London 2009.

Anna-Lena SENDER - holds the MA granted by Erasmus Mundus joint programme "Euroculture (Society, Politics and Culture in the Global Context)". Currently works at the University of Groningen as the Project Assistant at DAAD German Academic Exchange Service. Actice in the fields of sociology, cultural studies, EU and European studies, politics and international relations. Ambassador for the Euroculture Programme. 